\title{
Range Fertilization in the Northern \\ Great Plains
}

\section{J. ROSS WIGHT}

Highlight: Nutrient deficiency, primarily nitrogen $(N)$, is a major plant growth-limiting factor on northern Great Plains rangelands. Applications of 30 to $50 \mathrm{lb}$ N/acre/year have commonly doubled forage production with an $N$-use efficiency of about $20 \mathrm{lb}$ dry matter/lb $N$ applied, or in grazing situations about $1 \mathrm{lb}$ beef/lb $N$ applied.

Range fertilization can also increase water-use efficiency and improve forage quality and palatability. With applications of $50 \mathrm{lb}$ N/acre/year or less, changes in species composition are gradual and can largely be controlled by timing of fertilizer applications and by season and intensity of grazing. Drastic changes in species composition are usually limited to applications greater than $150 \mathrm{lb} N /$ acre/year.

The northern Great Plains as described by Lodge (1970) covers approximately 400,000 square miles. Its general boundaries are the Rocky Mountains from the Wyoming-Colorado border north to Edmonton, Alberta, Canada, thence southeast to the intersection of the 98th meridian and the U.S.-Canadian border, thence south along the 98th meridian to the 41 st parallel, and thence west to the Rocky Mountains. Native range accounts for approximately $70 \%$ of the land area and is primarily of the mixed prairie types with some tall grass prairie on the eastern extreme and some short grass prairie on the southwestern extreme. The Chestnut, Brown, and Dark Brown soils comprise the major soil groups within the area.

The northern Great Plains has a climate which is generally considered harsh and extreme. Precipitation is irregular and often in short supply. In the east, annual precipitation averages more than 20 inches and in the north and west, as little as 10 inches per year. Among-year variation is even greater, particularly the seasonal precipitation, which often varies $100 \%$ or more. However, precipitation patterns within the northern Great Plains affect the vegetation more than does the total amount. About three-fourths of the annual precipitation occurs during the 6-month growing season (April through September) and about half during May, June, and July. Average growing season of the northern Great Plains decreases from 160 to 116 days going from south to north.

Livestock production is a major segment of the economy in the northern Great Plains. Lodge (1970) estimated that this area supports some 12 million animal units of beef cattle and sheep. However, increasing demands for wheat and other cultivated crop products have resulted in the conversion of large acreages of range to crop land. Thus, to meet the

The author is range scientist, U.S. Department of Agriculture, Agricultural Research Service, Northern Plains Soil and Water Research Center, Sidney, Montana 59270.

The study is a contribution from the Western Region, U.S. Dep. Agr., Agr. Res. Serv., in cooperation with the Montana Agricultural Experiment Station, Journal Series No. 616. demands for red meat products, more emphasis is being placed on better and more intensive management systems. Only within the past few years has manipulation of soil fertility (fertilization) been considered seriously as a range management tool. The purpose of this paper is to summarize, in terms of forage and animal responses, range fertilization research conducted in the northern Great Plains.

\section{A Grassland Ecosystem}

A mixed prairie plant community described by Wight and Black (unpublished data) is typical of coarse- to medium-textured upland range sites in the northern Great Plains. Annual precipitation averaged about 13.5 inches, with $80 \%$ received in April-September. The soil with a well-developed lime layer beginning at 12 to 18 inches and with 80 to $90 \%$ of the root material in the upper 12 inches indicated a history of limited precipitation. Major forage species included western wheatgrass (Agropyron smithii), blue grama (Bouteloua gracilis), prairie Junegrass (Koleria cristata), needleandthread (Stipa comata), and some upland sedges-primarily threadleaf sedge (Carex filifolia) and needleleaf sedge (Carex eleocharis). Aboveground dry matter production averaged $954 \mathrm{lb} / \mathrm{acre} /$ year over a 6 -year period. Root biomass in the top 12 inches of soil profile was approximately $18,500 \mathrm{lb} /$ acre, an amount similar to that reported by Goetz (1969) at Dickinson, N. Dak., but a little less than that reported by Power and Alessi (1971) at Mandan, N. Dak. This amount of root material represented 188 and $13.9 \mathrm{lb} /$ acre of nitrogen $(\mathrm{N})$ and phosphorus $(\mathrm{P})$, respectively. Total $\mathrm{N}$ and $\mathrm{P}$ requirements for this mixed prairie plant community was 59 and $4.9 \mathrm{lb} / \mathrm{acre} /$ year, respectively, with 12 and $1.4 \mathrm{lb} /$ acre of $\mathrm{N}$ and $\mathrm{P}$, respectively, appearing in aboveground biomass.

\section{Nutrient Cycling}

Because of the large quantity of low N-content root material in the soil, large quantities of inorganic $\mathrm{N}$ are immobilized when $\mathrm{N}$ fertilizers are applied. Power (1972) estimated that in central North Dakota up to $300 \mathrm{lb} \mathrm{N} /$ acre may be immobilized by this "N-sink." To maintain a pool of available inorganic $\mathrm{N}$, the "sink" requirements must be satisfied. This theory helps to explain the apparent lack of response that has been obtained with low-rate applications of $\mathrm{N}$ on native range as compared with the two- and three-fold increases reported in the past decade with $\mathrm{N}$-rates of 100 $\mathrm{lb} / \mathrm{acre}$ or more.

Theoretically, once the soil system has been charged or enriched by fertilization, it should through decomposition cycle plant nutrients at a much higher level. While research results indicate that the nutrient cycling rate is increased by fertilization, it does not attain a level that is in balance with available water, i.e., not enough $\mathrm{N}$ is made available through 
decomposition for maximum use of available water as measured in terms of dry matter production. This condition exists primarily in colder climates where photosynthesis is more efficient than decomposition. In the northern Great Plains, time periods during which soil water and soil temperatures are at adequate levels for decomposition can be very short. To make maximum use, in terms of forage production and a limiting water supply, nutrient enrichment or fertilization must be practiced on a continuing basis despite the fact that very little $\mathrm{N}$ is removed from the ecosystem by grazing animals. Whether or not such practices are economical depends on several factors, including the kind and degree of plant responses and subsequent animal responses.

\section{Plant Responses}

\section{Forage Yield}

A good review of range fertilization research in the northern Great Plains has been published by Rogler and Lorenz (1974). From results of published research, it is apparent that $\mathrm{N}$ deficiencies do limit forage production in the northern Great Plains. Nearly every study reported that $\mathbf{N}$ fertilization increased forage production. Degree of response varied among sites with their variation in vegetation and prevailing climate and was also a function of fertilizer application rates. Single applications of $\mathrm{N}$ (50 lb/acre or less) have generally resulted in forage increases of less than $100 \%$ and have shown limited carryover or residual effect. At $\mathrm{N}$ applications above $100 \mathrm{lb} / \mathrm{acre}$, forage yields have increased 100 to $200 \%$ with a carryover or residual effect which lasts for several years, depending upon the application rate. Wight and Black (unpublished data) found yield increases of 40 and $80 \%$ the 6th year after single applications of 100 and $900 \mathrm{lb} \mathrm{N} / \mathrm{acre}$, respectively. However, applications of about $40 \mathrm{lb} \mathrm{N} / \mathrm{acre} /$ year can be expected to double forage yields. Low-rate applications also provide more flexibility to respond to varying climates and forage needs and reduce some of the potential hazards associated with high-rate applications, like nitrate toxicities and undesirable changes in species composition.

Nitrogen is the major growth-limiting plant nutrient. Usually when $\mathbf{P}$ was applied alone, there was little or no response. However, with high $\mathrm{N}$ rates (Wight and Black, 1972) or after years of $\mathrm{N}$ fertilization (Lorenz and Rogler, 1972) $\mathrm{P}$ becomes limiting; and there have been significant yield responses to $\mathrm{P}$ applications with forbs and shrubs responding more than grasses.

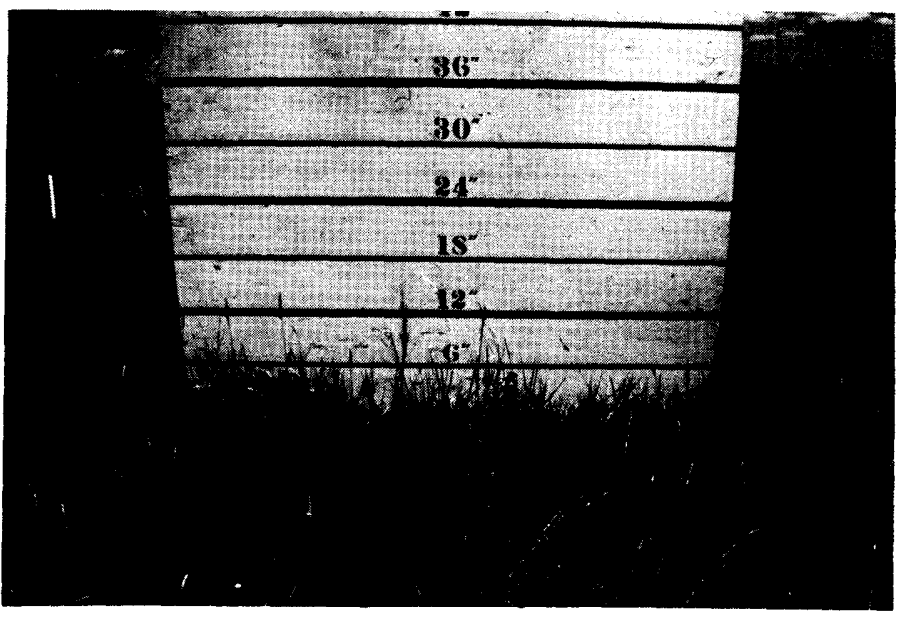

Unfertilized
In addition to $\mathrm{N}$ and $\mathrm{P}$, other plant nutrients like potassium, sulfur, and some micronutrients have been evaluated as fertilizer materials. Results have not indicated a need for these elements. However, if production rates are increased through use of $\mathrm{N}$ and $\mathrm{P}$, probably other nutrients will become limiting. While these nutrients are not now measurably limiting growth, plant levels are being reduced to the point where they may be limiting animal response.

\section{Species Composition}

Along with economic considerations, the effects of fertilization on species composition is a major consideration. Past research results indicated a differential response by species to nutrient enrichment, particularly $\mathrm{N}$. Usually, cool-season species, particularly western wheatgrass, have responded most to $\mathrm{N}$ fertilization. Some forage yield increases have been due almost entirely to western wheatgrass, a rhizomatous species which responds to $\mathrm{N}$ by increasing both in number and vigor. In one experiment (Wight and Black, unpublished data), $300 \mathrm{lb}$ N/acre increased western wheatgrass culms from 31 to $138 / \mathrm{ft}^{2}$ and average upstretched leaf length from 16 to 27 inches. As cool-season species increase, warm-season species decrease, particularly blue grama. With rates of 40 and $80 \mathrm{lb} \mathrm{N} /$ acre/year for an 8-year period, western wheatgrass culms increased an average of 528 and $788 \%$, respectively, while blue grama basal cover decreased an average of 26 and 44\% (Lorenz and Rogler, 1972). This effect can be somewhat offset by timing of fertilizer applications; late spring or summer applications tend to benefit warm-season species more than cool-season species (Rehm et al., 1972). However, if application rates are high enough so there is a significant carryover, then cool-season species will benefit the next spring to the detriment of warm-season grasses. Early grazing will also reduce the competitive advantage of cool-season species.

High $\mathrm{N}$ applications (usually in excess of $150 \mathrm{lb} / \mathrm{acre}$ ) may have drastic effects on species composition. Sometimes they beneficially decrease clubmoss (Selaginella densa) and threadleaf sedge and increase desirable perennial grasses. Sometimes responses are adverse; weedy species like tansy mustard (Descurainia sophia), cheatgrass (Bromus tectorum), and Japanese brome (B. japonicus) are greatly stimulated by high-rate $\mathrm{N}$ applications. These weedy invaders begin growth early in the spring and have a priority on available water and plant nutrients. Thus, if $\mathrm{N}$ is available from fertilization in the early spring or carryover from previous application, these

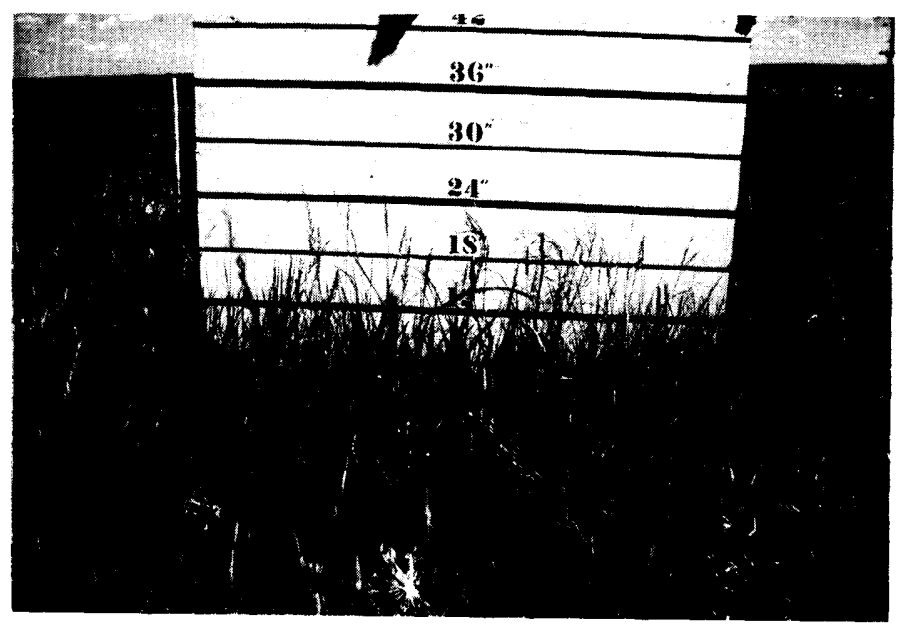

Fertilized 
species will benefit most and will gain a competitive advantage over more desirable perennial species. Fringed sagewort (Artemisia frigida), common on nearly all mixed prairie rangelands, shows a marked initial response to $\mathrm{N}$-fertilization at nearly all rates. The visual appearance of this response has caused much concern and has discouraged $N$ fertilization in many instances. However, when considered in proportion to the other species, fringed sagewort response to $\mathrm{N}$-fertilization is not as great as it appears and usually decreases after the first year.

Fertilization used with herbicides has improved range condition. Rogler and Lorenz (1974) changed a range from poor condition class to excellent in a 3-year period with applications of $40 \mathrm{lb} \mathrm{N} /$ acre/year plus spraying with 2,4-D and without any grazing deferment. Rogler and Lorenz (1957) also reported in one study that 2 years of fertilizing a heavily grazed range improved range conditions more than did 6 years of deferment.

Most forbs and shrubs can be effectively controlled by herbicide applications. Control of the annual bromegrasses, cheatgrass and Japanese brome, is difficult; and when these species are components of the native range, fertilization could be a hazardous practice. However, progress is being made in developing effective herbicides for these species.

\section{Forage Quality}

Forage quality is significantly affected by fertilization. Up to two-fold increases in forage $\mathrm{N}$ and $\mathrm{P}$ contents were reported by Black and Wight (1972) with $\mathrm{N}$ and $\mathrm{P}$ applications of 100 $\mathrm{lb} /$ acre or more. Sometimes, the $\mathrm{N}$ content or crude protein is higher than that actually needed by a particular class of animals. Rogler and Lorenz (1965) found no measurable increase in yearling gains per head as a result of grazing fertilized grass high in protein and concluded that at least during the early part of the year the protein content was greater than the minimal requirements. In this study, mid-May crude protein content was increased 38 and $47 \%$ by applications of 40 and $80 \mathrm{lb} \mathrm{N} /$ acre/year, respectively. In October, crude protein content still averaged 22 and $36 \%$ higher for the 40 and $80 \mathrm{lb}$ N/acre/year treatments, respectively, than for the check plots. Black (1968) working on a $P$ deficient glacial till soil reported that $N$ alone reduced $P$ content and that a single application of 20 or $40 \mathrm{lb} \mathrm{P} /$ acre raised the $P$ content of native range from 0.10 to $0.12 \%$. On a similar site, Black and Wight (1972) found that $100 \mathrm{lb} \mathrm{P/acre}$ increased $P$ content of mature grasses to about $0.20 \%$, slightly more than the $0.18 \%$ recommended by the National Research Council (1970) for normal growth of beef cattle.

Palatability of fertilized range is greatly enhanced by $\mathrm{N}$ fertilization as evidenced by preferential grazing of fertilized plots by nearly all classes of livestock, including wildlife. This feature of range fertilization necessitates management systems where grazing is restricted to fertilized or nonfertilized pasture units. Given free choice the animals will nearly always graze or overgraze fertilized areas and ignore nonfertilized areas. Fertilizer can also be used to increase animal utilization of unpalatable species such as red threeawn (Aristida longiseta) (Lorenz, personal communication) and porcupine grass (Stipa spartea) (Roath and Ryerson, unpublished data).

Fertilizing introduced species, especially crested wheatgrass (Agropyron cristatum), has been more common than fertilizing native range. Recommended rates vary with precipitation zones, fertilizer costs, and forage values. In areas with 15 inches or less annual precipitation, recommended rates are usually less than $100 \mathrm{lb} \mathrm{N} /$ acre/year with rates of 30 to 60 lb N/acre/year being most common. Burt et al. (1971) reported a formula for calculating residual $\mathrm{N}$ for crested wheatgrass based on the March through June precipitation for the years since the last $\mathrm{N}$ application and the longtime March through June precipitation average. This calculated residual $\mathrm{N}$ can then be considered when making an N-rate recommendation.

Introduced species respond well to fertilization. In eastern Montana, applications of 20, 40, and $60 \mathrm{lb} \mathrm{N} /$ acre/year increased forage yields of intermediate wheatgrass (Agropyron intermedium) from 2,000 to $2,500,3,100$, and 3,250 $\mathrm{lb} / \mathrm{acre} / \mathrm{year}$, respectively, and Russian wildrye (Elymus junceus) yields from 2,000 to 2,900, 3,100, and 3,500 $\mathrm{lb} / \mathrm{acre} /$ year, respectively, over a 5 -year period (Black and Reitz, 1969). Crested wheatgrass fertilized with 0,40 , and 80 lb N/acre/year produced an average hay crop of $1,680,3,040$, and $3,260 \mathrm{lb} / \mathrm{acre} /$ year, respectively, over a 10 -year period (Rogler and Lorenz, 1969). Fertilizing introduced species has generally been more productive than fertilizing native range, especially in terms of grazeable forage or beef production. Lorenz and Rogler (1971) reported that Russian wildrye fertilized with $40 \mathrm{lb}$ N/acre/year produced $163 \mathrm{lb}$ beef/acre/year compared with $106 \mathrm{lb} / \mathrm{acre} /$ year by native range under the same fertilizer and grazing treatments.

In comparing response of native range to introduced pastures under fertilization treatments, beef production usually increases disproportionately as compared with dry matter production. Usually, tame pastures produce a greater proportion of grazeable forage than do native ranges. From data reported by Rogler and Lorenz (1965 and 1969), native range fertilized with 0,40 , and $80 \mathrm{lb}$ N/acre/year produced average dry matter yields of $1,978,2,950$, and 3,741 $\mathrm{lb} / \mathrm{acre} /$ year, respectively; for a similar period, the same $\mathrm{N}$ treatments on crested wheatgrass produced $1,740,2,760$, and $3,120 \mathrm{lb} / \mathrm{acre} /$ year, respectively. For these same treatments beef yields were 48,90 , and $118 \mathrm{lb} /$ acre/year, respectively, for the native range and 101,169 , and $176 \mathrm{lb} /$ acre/year, respectively, for crested wheatgrass. Crested wheatgrass yield determinations in this study were made at 1 -inch heights rather than at ground surface and, therefore, were slightly underestimated.

\section{Animal Responses}

While research has shown that fertilization increases forage production and improves forage quality as measured by increased crude protein and $\mathbf{P}$ content, little work has been done to show benefits in terms of livestock production. The work reported by Rogler and Lorenz (1974) is probably the most complete to date in this area. In one study, they found that applying 40 and $80 \mathrm{lb} \mathrm{N} /$ acre/year to native range increased beef production from 50 to 97 and 125 $\mathrm{lb}$ - beef/acre/year, respectively, over an 11-year period. However, gains per head were not significantly increased by fertilization. In other studies, they found that applications of $40 \mathrm{lb} \mathrm{N} /$ acre/year on crested wheatgrass and Russian wildrye pastures increased beef production by 68 and $90 \mathrm{lb} / \mathrm{acre} /$ year, respectively. In Nebraska, Burzlaff and Diagger (1972) reported that applications of $30 \mathrm{lb} \mathrm{N}$ and $4 \mathrm{lb}$ of $\mathrm{P} /$ acre/year increased beef gains $12 \%$ the first year, $54 \%$ the second year, and $59 \%$ the third year. Choriki et al. (1969) reported that in central Montana, an application of $300 \mathrm{lb}$ N/acre increased beef production from 24 to $120 \mathrm{lb} /$ acre the first year after application. With an additional $100 \mathrm{lb} \mathrm{P} / \mathrm{acre}$, yields were 
increased to $150 \mathrm{lb}$ beef/acre. Residual effects of these treatments could be expected to last several years. In a recent grazing trial on a mixed prairie range in east-central Montana, an application of $150 \mathrm{lb} \mathrm{N}$ and $50 \mathrm{lb} \mathrm{P} /$ acre increased beef production from 20 to $63 \mathrm{lb} /$ acre the first year after treatment (Cade, 1974).

Other important aspects of animal response to range fertilization have not yet been evaluated. Animal fertility, calf weights, and similar aspects of animal response are likely improved by the increased nutrition resulting from fertilized range. These factors can have an important influence on evaluating fertilization treatments.

\section{Nitrate Toxicities}

Accumulation of nitrates in ground water and at toxic levels in forage under range fertilization has been a concern. To date, no incidence of either ground water contamination or nitrate toxicity due to fertilization has been reported. Power (1970) found no nitrate movement below 3 feet in the soil profile after applying up to $360 \mathrm{lb} \mathrm{N} /$ acre. Choriki et al. (1969) reported that with fertilizer application of up to $600 \mathrm{lb}$ N/acre only green needlegrass (Stipa viridula) accumulated enough nitrate to be considered toxic and that the levels were toxic only in late June. Houston et al. (1973) found that some annual forbs accumulated toxic levels of nitrates at $\mathrm{N}$ application rates of $200 \mathrm{lb} /$ acre or more. Where these forbs are a major portion of the animal's diet, nitrate toxicity could certainly occur.

\section{Nitrogen-Use Efficiency}

$\mathrm{N}$-use efficiency is the units of forage or meat produced per unit of $\mathrm{N}$ applied and is calculated as the difference in production between fertilized and nonfertilized plots divided by $\mathrm{N}$-application rate. To compare various $\mathrm{N}$ rates over time, $\mathrm{N}$ rates are expressed in terms of annual $\mathrm{N}$-rate equivalents. For example, the efficiency of a single application of $150 \mathrm{lb} \mathrm{N} /$ acre measured over a 3-year period is about the same as $50 \mathrm{lb} /$ acre applied annually for 3 years. Using the data of Houlton (1975), $\mathrm{N}$-use efficiencies were calculated for various rates of $\mathrm{N}$ and total herbage production measured over a 6-year period on a mixed prairie upland range site near Havre, Mont. Total $\mathrm{N}$ applications for the 6-year period included 50,100,150, 200, $250,300,400,450,500,600,750$, and $900 \mathrm{lb} \mathrm{N} /$ acre applied in one, two, or three applications. In the fall of 1968, seven replicated plots were fertilized with ammonium nitrate at the rates of $0,50,100,150,200,250$, and $300 \mathrm{lb} \mathrm{N} / \mathrm{acre}$. Two-thirds of each plot received the same treatment in 1969, and one-third received the same treatment in 1970. The N-use efficiency, $(Y)$ was closely related $\left(R^{2}=0.93\right)$ to the annual rate equivalents $(X)$ by the function $Y=A e^{b x}$, where $A=28.9$, $\mathrm{b}=0.00905$, and $\mathrm{e}$ is the base of the natural logarithm (Fig. 1). $\mathrm{N}$-use efficiencies calculated with data from eastern Montana (Wight, 1975) and central North Dakota (Power and Alessi, 1971) followed this same general relationship.

Frequency of $\mathrm{N}$ application (Fig. 1) whether a single application or several proportionally smaller ones with the same total magnitude had little effect on $\mathrm{N}$-use efficiency. This is generally true throughout the northern Great Plains except when initial or single applications are insufficient to at least partially satisfy the $\mathrm{N}$-sink requirements. This initial $\mathrm{N}$-requirement may vary from about 50 to more than $100 \mathrm{lb}$ $\mathrm{N} /$ acre and increases as precipitation increases and temperature gradients decrease. To obtain maximum forage yields rather

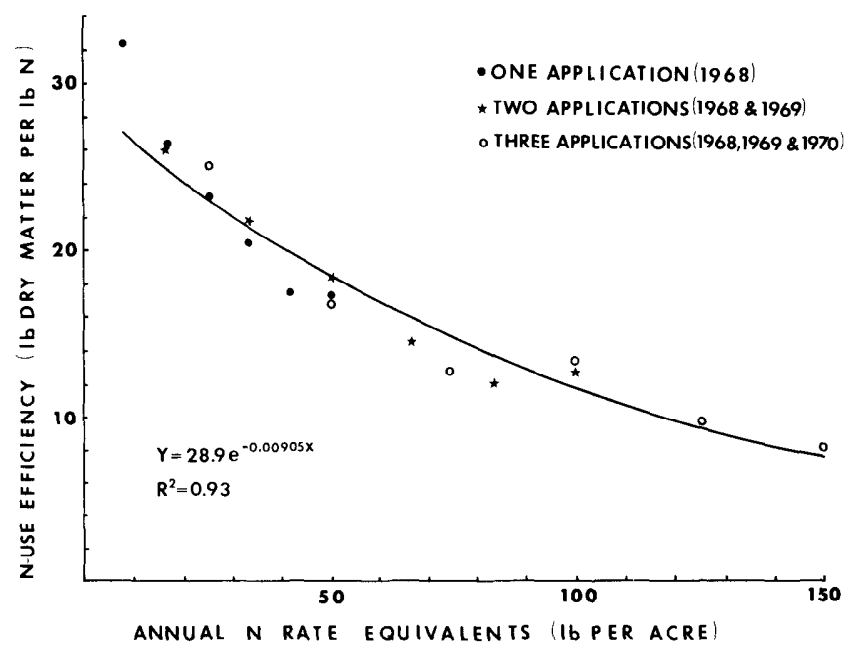

Fig. 1. Relationship between $N$-use efficiency and annual rate equivalents of fertilizer $N$ (From data by Houlton, 1975).

than efficiency, the initial $\mathrm{N}$-requirements are somewhat greater.

Using the function in Figure 1, N-use efficiencies can be calculated for any $\mathrm{N}$ rate. For Example, with an annual $\mathrm{N}$-rate equivalent of $40 \mathrm{lb} / \mathrm{acre}$, each $\mathrm{lb}$ of $\mathrm{N}$ will produce an additional $20 \mathrm{lb}$ of dry matter. Approximately $75 \%$ of the total forage production on a normal upland range site is composed of grazeable species (Larry M. White, unpublished data). Assuming 75\% utilization of these species, $56 \%$ of the additional forage will be consumed which represents about 11 $\mathrm{lb}$ of forage and is only slightly more than the $10.5 \mathrm{lb}$ calculated as the amount of forage necessary to produce $1 \mathrm{lb}$ of gain on normal-growth yearling steers grazing a blue grama-western wheatgrass summer pasture (National Research Council, 1970). Or, $1 \mathrm{lb}$ fertilizer $\mathrm{N}$ will produce 1 additional $\mathrm{lb}$ of beef when $\mathrm{N}$ is applied at an annual rate equivalent of 40 $\mathrm{lb} / \mathrm{acre}$. This generalization agrees with the results reported by Lorenz and Rogler (1971) where $40 \mathrm{lb} \mathrm{N} / \mathrm{acre} /$ year produced an additional $42 \mathrm{lb}$ beef/acre/year over a 6-year period. Hyder et al. (1975) reported that on a short-grass prairie, $20 \mathrm{lb}$ N/acre/year produced an additional $22 \mathrm{lb}$ beef/acre/year: lower total production than in the mixed prairie but about the same $\mathrm{N}$-use efficiency. Thus, in general terms, fertilizer applications of 30 - to $50-\mathrm{lb} \mathrm{N} /$ acre annual rate equivalents on upland range sites of mixed prairie will produce an additional $1 \mathrm{lb}$ beef/lb $\mathrm{N}$ applied.

Introduced species show a $\mathrm{N}$-use efficiency-annual $\mathrm{N}$ rate equivalent relationship similar to that of native range. Actual $\mathrm{N}$-use efficiencies for introduced pastures vary with factors like species and stand condition but generally are higher than those for native range. In terms of beef production per unit of $\mathrm{N}$, the introduced species have an advantage over native species since nearly all of the increased production is grazeable, whereas, in native range there is always a weedy portion that is not grazed. Using data from Lorenz and Rogler (1971), N-use efficiencies of 1.0, 1.7, and 2.2 were calculated for native, crested wheatgrass, and Russian wildrye, respectively, fertilized with $40 \mathrm{lb} \mathrm{N} / \mathrm{acre} /$ year.

\section{Water-Use Efficiency}

Use of fertilizer, particularly $\mathrm{N}$, has significantly increased the efficiency with which soil water is used. Because of the close relationship between water-use efficiency (WUE) and 
forage yields, WUE response to fertilization has been as large as forage responses. The data of Smika et al. (1965) (Fig. 2) graphically demonstrate the relationship between forage production and available water as it is affected by $\mathrm{N}$ fertilization. The data also indicate the importance of maintaining an adequate available $\mathrm{N}$ level to most efficiently use available soil water.

Not only does fertilization improve WUE, but it also has the potential of increasing the amount of precipitation that becomes available for plant use (Wight and Black, 1972). The stimulated root system of fertilized vegetation extracts more water from the profile than nonfertilized vegetation. Thus, whenever overwinter precipitation fully recharges the profile, fertilized range will have more water available for plant use because it will, in effect, be drawing water from a larger, soil-water reservoir than nonfertilized range. Also, the efficiency of overwinter recharge increases as the soil profile becomes drier (Black and Power, 1965).

\section{Fertilization and Drought}

The question of whether or not $\mathrm{N}$ fertilizer aggravates a droughty condition is often asked. So far, little evidence has been presented to indicate that it does. During 1971, water was critically limiting in the northeastern part of Montana and experimental plots were not harvested because of lack of growth (Ford and Siddoway, unpublished data). The next year, 1972, was a good moisture year and yield responses to fertilizer treatments indicated no ill-effects from the combination of fertilization and drought. In fact, high yields indicated almost complete carryover of the unused $\mathrm{N}$ fertilizer during the drought year. Rapid withdrawal of soil water by fertilized vegetation tends to advance maturation and senescence dates-particularly in droughty years. This shortening effect on the growing season is somewhat offset by an earlier "green-up" on fertilized as compared with nonfertilized range.

\section{Fertilizer Materials}

Because range fertilization has generally necessitated a broadcast method of application, readily available inorganic source materials have been used almost exclusively. For N, ammonium nitrate and ammonium sulfate are the common sources. Inorganic fertilizers compared in terms of available

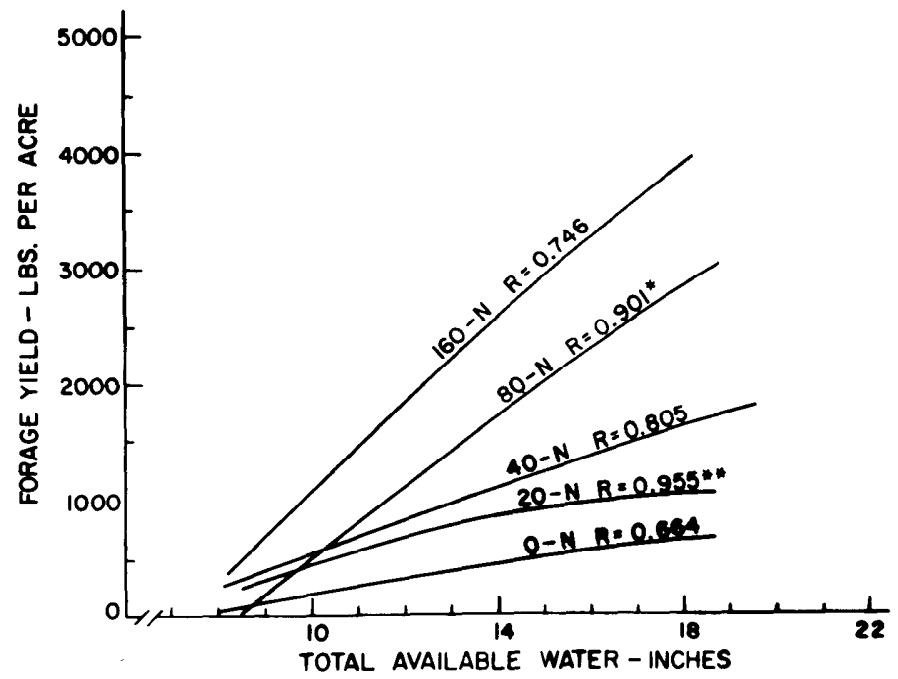

Fig. 2. Effects of available water on native grass forage production with different rates of $N$ fertilizer applied annually (Smika et al., 1965). nutrients have been about equally effective. Some studies have included manures which, when applied in adequate quantities, have been effective (Heady, 1952; Smoliak, 1965). Benefits from manures may not be limited to just nutrient enrichment but may also include some beneficial mulch effects and improvement of the soil's physical characteristics.

Recent research has shown urea is a potentially cheaper and more available source of N. Power (1974) reported that at low $\mathrm{N}$-rates (less than $100 \mathrm{lb} \mathrm{N} / \mathrm{acre}$ ) broadcast urea was about as effective as ammonium nitrate. Power (personal communication) has also conducted some research with some slow-release $\mathbf{N}$ formulations. The potential advantage of such fertilizers would be to evenly distribute available $\mathrm{N}$ throughout the growing season and would benefit warm- as well as cool-season species. To date, such fertilizer formulations have shown very little promise for semiarid ranges.

\section{Use of Range Fertilization}

Interest by ranchers in fertilization as a management practice has increased considerably in the past few years. In 1973, a questionnaire was sent to county agricultural extension agents of 12 eastern Montana counties and eight bordering North and South Dakota counties regarding range fertilization practices in their counties. Replies were received from four Montana counties, four North Dakota counties, and one South Dakota county and represented approximately 7.5 million acres of native range and 0.5 million acres of introduced or tame pastures. Results of the survey indicated about $1.2 \%$ of the native range and $9.5 \%$ of the introduced pastures have been fertilized. Most $\mathrm{N}$ applications (68\% for native and $83 \%$ for introduced pastures) ranged from 0 to 50 $\mathrm{lb} \mathrm{N} / \mathrm{acre}$ and were frequently accompanied by small $\mathrm{P}$ applications. Only $1 \%$ of the applications exceeded $150 \mathrm{lb}$ $\mathrm{N} / \mathrm{acre}$. In response to the question "What percentage of ranch operators who had used fertilizer on rangeland would use it again?", the county agents estimated that $70 \%$ would on native range and $92 \%$ would on introduced pastures. In general, range was fertilized more in the North and South Dakota counties than in Montana counties. The following is typical of comments received on the questionnaire: "More and more are fertilizing grassland each year, especially the domestic grasses. Once a rancher sees the results of the first year of fertilizing, he sticks with it. The fellows are very cautious about fertilizing native ranges. Those fertilizing domestic grasses are applying right around 30 to $40 \mathrm{lb}$ actual N."

One county agent indicated that ranchers were skeptical of fertilizing native range because of management requirements. This is an often overlooked area of concern. Whole pasture units must be fertilized to make efficient use of all range and to prevent overgrazing. However, in some specialized situations, fertilizing of specific areas of a pasture unit can improve livestock distribution.

Most states and provinces within the northern Great Plains have published fertilization recommendations through their extension service programs. Unless a legume is involved, recommendations are usually limited to $\mathrm{N}$ at rates of 30 to 75 $\mathrm{lb} / \mathrm{acre} /$ year. Effective $\mathrm{P}$ recommendations can be made the basis of soil tests.

\section{Conclusion}

Results of past range fertilization research indicate that $\mathrm{N}$ deficiency is a major limiting factor in forage production in 
the northern Great Plains. Under proper management, annual applications of 30 to $50 \mathrm{lb} \mathrm{N} /$ acre or periodic application of comparable amounts can increase forage production 50 to $100 \%$ in most areas of the northern Great Plains. In terms of $\mathrm{N}$-use efficiency, 30 to $50 \mathrm{lb} \mathrm{N} /$ acre will produce 18 to $22 \mathrm{lb}$ dry matter/lb $\mathrm{N}$ applied or approximately $1 \mathrm{lb}$ beef/lb $\mathrm{N}$ applied. Higher rates will produce more beef but less efficiently. As expected, the biggest forage increases from fertilization are obtained on the most productive range sites. Introduced pastures are generally more productive than native pastures and, for grazeable forage or animal production, have a higher potential to respond to fertilization than do native pastures.

The problem regarding fertilization effect on species composition has not yet been resolved, nor will it be resolved until more fertilization research can be conducted under grazing situations for long enough periods to adequately determine changes and trends in species composition under climatic variations. Range fertilization research is at a point where emphasis must be placed on using grazing animals. Plant-animal-management interactions under fertilization regimes must be studied if research is to meet the needs of the livestock ind ustry.

Whether range fertilization pays is the main question asked by ranchers. The economic feasibility of fertilization practices cannot be determined by research alone but is subject to the fluctuations of prices in the livestock industry and needs of individual ranching situations. In the past 3 years, $N$ costs have tripled. Research, however, can supply information relative to expected yield increases from fertilizer applications and recommended application rates. The pound of beef/pound of $\mathrm{N}$ relationship should be helpful in making effective management decisions.

Where economically feasible, range fertilization can be an effective and practical management tool. It offers the opportunity to increase forage production to meet the increasing forage demands without buying new land with its associated overhead expenses, like taxes, fencing, and water development. Also, currently, rangeland is difficult, if not impossible, to acquire and when available it is not economically priced. Increasing forage requirements must be produced on existing lands. With the low conversion efficiency of beef animals and an ever-increasing world demand for protein, farmland used for grain production will not likely be converted to grass; the opposite is more likely to happen. Thus, range fertilization may become increasingly important as a range management tool in the quest for increased levels of forage production.

\section{Literature Cited}

Black, A. L., and J. F. Power. 1965. Effect of chemical fallow methods on moisture storage, wheat yields, and soil erodibility. Soil Sci. Soc. Amer. Proc. 29:465-468.

Black, A. L. 1968. Nitrogen and phosphorus fertilization for production of crested wheatgrass and native grass in northeastern Montana. Agron. J. 60:213-216.

Black, A. L., and L. L. Reitz. 1969. Row spacing and fertilization influences on forage and seed yields of intermediate wheatgrass, Russian wildrye, and green needlegrass on dryland. Agron. J. 61:801-805.

Black, A. L., and J. Ross Wight. 1972. Nitrogen and phosphorus availability in a fertilized rangeland ecosystem of the northern Great Plains. J. Range Manage. $25: 456-460$.

Burt, Oscar, M. S. Stauber, and Ray Choriki. 1971. Economic uses of nitrogen on crested wheatgrass in central Montana. Proc., Twenty-second Annu. Fert. Conf. of the Pacific Northwest,
Bozeman, Mont., July 12-15, 1971. p. 77-78.

Burzlaff, D. F., and L. A. Daigger. 1972. Fertilizing native range. Quarterly, Univ. of Nebraska, College of Agr. 19(1) Spring 1972.

Cade, Lee. 1974. About range fertilization-there's much to learn. Montana Farmer-Stockman 62(1): 6-7.

Choriki, Raymond T., D. E. Ryerson, and A. L. Dubbs. 1969. Evaluation of nitrogen use and methods of application on mixed prairie vegetation in Montana in relation to forage yield, change in composition of vegetation, residual nitrogen, nitrate poisoning, and beef gain per acre. Proc., Twentieth Annu. Pacific Northwest Fert. Conf., Spokane, Wash., July 8-10. p. 182-191a.

Goetz, Harold. 1969. Root development and distribution in relation to soil physical conditions on four different native grassland sites fertilized with nitrogen at three different rates. Can. J. Plant Sci. 49:753-760.

Heady, Harold F. 1952. Reseeding, fertilizing, and renovating in an ungrazed mixed prairie. J. Range Manage. 5:144-149.

Houlton, Harold A. R. 1975. Range vegetation response to nitrogen fertilization in north central Montana. Proc. Range Fert. Symp., Havre, Mont., July 1974. Montana Agr. Exp. Sta. Res. Rep. 70. Montana State Univ., Bozeman.

Houston, W. R., L. D. Sabatka, and D. N. Hyder. 1973. Nitrate-nitrogen accumulation in range plants after massive $\mathrm{N}$ fertilization on short-grass plains. J. Range Manage. 26:54-57.

Hyder, D. N., R. E. Bement, E. E. Remmenga, and D. F. Hervey. 1975. Ecological responses of native plants and guidelines for management of shortgrass range. U.S. Dep. Agr., Agr. Res. Serv. Tech. Bull. No. $1503.87 \mathrm{p}$.

Lodge, R. W. 1970. Complementary grazing systems for the northern Great Plains. J. Range Manage. 23:268-271.

Lorenz, Russell J., and George A. Rogler. 1971. Increasing production of native and seeded pastures with nitrogen fertilizer. Proc., Twenty-second Annu. Fert. Conf. of the Pacific Northwest, Bozeman, Mont., July 13-15, 1971. p. 65-76.

Lorenz, Russell J., and George A. Rogler. 1972. Forage production and botanical composition of mixed prairie as influenced by nitrogen and phosphorus fertilization. Agron. J. 64:244-249.

National Research Council. 1970. Nutrient requirements of beef cattle. Fourth revised edition. Nat. Acad. of Sci., Washington, D.C. 55 p.

Power, J. F. 1970. Leaching of nitrate-nitrogen under dryland agriculture in the northern Great Plains, p. 111-122. In: Relationship of agriculture to soil and water pollution. Cornell Univ. Press.

Power, J. F., and J. Alessi. 1971. Nitrogen fertilization of semiarid grasslands: Plant growth and soil mineral $\mathrm{N}$ levels. Agron. J. 63:277-280.

Power, J. F., 1972. Fate of fertilizer nitrogen applied to a northern Great Plains rangeland ecosystem. J. Range Manage. 25:367-371.

Power, J. F. 1974. Urea as a nitrogen fertilizer for Great Plains grasslands. J. Range Manage. 27:161-164.

Rehm, G. W., W. J. Moline, and E. J. Schwartz. 1972. Response of a seeded mixture of warm-season prairie grasses to fertilization. J. Range Manage. 25:452-456.

Rogler, George A., and Russell J. Lorenz. 1957. Nitrogen fertilization of northern Great Plains rangelands. J. Range Manage. 10:156-160.

Rogler, G. A., and R. J. Lorenz. 1965. Nitrogen fertilization of natural grasslands in the northern plains of the United States. Proc. 9th Internatl. Grassl. Congr. (Sao Paulo, Brazil) p. 1327-1330.

Rogler, George A., and Russell J. Lorenz. 1969. Pasture productivity of crested wheatgrass as influenced by nitrogen fertilization and alfalfa. North Dakota Agr. Exp. Sta. Tech. Bull. No. 1402.

Rogler, George A., and Russell J. Lorenz. 1974. Fertilization of mid-continent range plants. p. 231-254. In: D. A. Mays (Ed.). Forage Fertilization. Amer. Soc. Agron., Crops Sci. Soc. Amer., and Soil Sci. Soc. Amer.

Smika, D. E., H. J. Haas, and J. F. Power. 1965. Effects of moisture and nitrogen fertilizer on growth and water use by native grass. Agron. J. 57:483-486.

Smoliak, S. 1965. Effects of manure, straw and inorganic fertilizers on northern Great Plains ranges. J. Range Manage. 18:11-15.

Wight, J. Ross. 1975. A summary of range fertilization research conducted by the Northern Plains Soil and Water Research Center. Proc. of the Range Fert. Symp., Havre, Mont., July 1974. Montana Agr. Exp. Sta. Res. Rep. 70. Montana State Univ., Bozeman. 8 p.

Wight, J. Ross, and A. L. Black. 1972. Energy fixation and precipitation-use efficiency in a fertilized rangeland ecosystem of the nor thern Great Plains. J. Range Manage. 25:376-380. 